\title{
MYOTONIC DYSTROPHIES: GENETICALLY-BASED DISEASES DUE TO TOXIC RNA
}

\author{
CARLO PELLICCIARI $(*)$
}

RIASSUNTO. - Le distrofie miotoniche (DM, le forme più diffuse di distrofia muscolare, dopo la distrofia di Duchenne) sono malattie degenerative a base genetica, che mostrano caratteristiche cliniche assai variabili e sono contraddistinte da miotonia (cioè da una prolungata contrazione della muscolatura scheletrica dopo breve stimolazione) e da rallentato rilassamento muscolare dopo contrazione volontaria. Ne esistono due forme: la più grave, detta DM1 (o malattia di Steinert) a la più leggera, DM2. E' ampiamente accettato che la patogenesi delle DM dipenda dall'accumulo intranucleare di sequenze di RNA espanse, che esercitano un'azione tossica sulla funzionalità cellulare, in dipendenza del sequestro, in localizzazioni nucleari ectopiche, di fattori proteici essenziali alla maturazione dei trascritti. Scopo di questo mini-simposio è descrivere le caratteristiche genetiche e cellulari delle DM, e di dimostrare come la ricerca di base possa fornire indicazioni significative per la diagnosi e la terapia.

$* * *$

ABSTRACT. - Myotonic dystrophies (DMs, the second most diffuse forms of muscular dystrophy, after Duchenne dystrophy) are genetically-based degenerative neuromuscular diseases exhibiting widely variable clinical features and characterized by myotonia (i.e., a prolonged contraction of skeletal muscles after short stimulation) and a delayed muscle relaxation after voluntary contraction. There are two form of DMs: the more severe DM1 (or Steinert's disease), and the milder form DM2. The intranuclear accumulation of expanded RNAs is considered as the pathogenetic factor of DMs: the presence of these RNAs exerts a toxic action on cell function which essentially depends on the ectopic sequestration of nuclear protein factors involved in the processing of transcripts. The aim of this mini-symposium is to describe the genetic and cellular bases of DMs, showing how the results of basic research may provide important clues for both diagnosis and therapy.

${ }^{(*)}$ Dipartimento di Biologia e Biotecnologie "Lazzaro Spallanzani”, Laboratorio di Biologia Cellulare e Neurobiologia, Università degli Studi di Pavia, Pavia, Italy E-mail: pelli@unipv.it 
Myotonic dystrophies (DMs) are genetically-based degenerative neuromuscular diseases exhibiting widely variable clinical features; they may arise at any age, and have a slowly progressive course. DMs are characterized by myotonia (i.e., a prolonged contraction of skeletal muscles after short stimulation) and by a delayed muscle relaxation after voluntary contraction. They are the second most diffuse forms of muscular dystrophy, after Duchenne dystrophy, with a prevalence 1:8.000. It is estimated in Italy about 8-10.000 patients affected by DM.

There are two form of DMs: DM1 (or Steinert's disease) is more severe and is caused by an unstable expansion of CTG nucleotide triplets in the 3' non-coding region of the DMPK gene; DM2 is the milder form, and depends on the expansion of the CCTG tetraplet in the first intron of the CNP (ZNF9) gene.

It is widely accepted that the pathogenesis of DMs is due to the intranuclear accumulation of expanded RNAs whose toxic action essentially depends on the ectopic sequestration of protein factors involved in the processing of transcripts: as a consequence, the whole function of muscle cells is affected.

The aim of this mini-symposium is to describe the genetic and cellular bases of DMs and to demonstrate how the results of the scientific research may provide important clues for both diagnosis and therapy.

The invited speakers are well known scientists, active in the field of dystrophy and more generally of skeletal muscle cell biology.

Denis Furling is a CNRS researcher at the Institut de Myologie, in Paris. He completed his $\mathrm{PhD}$ at the Laval University of Québec (Canada) in 1997, where he followed his post-doctorate with the neurologist Professor Jack Puymirat, at the Faculty of Medicine: here he started his research on myotonic dystrophy which he then continued after his return to France in 2000. Denis Furling has been especially working on the alterations in the myogenic program provoked by CTG expansions, searching for the molecular mechanisms involved in these modifications: to this aim, he developed in vivo and in vitro models reproducing some of the molecular anomalies of DMs. He is presently interested in the reduced proliferative capacity of myogenic precursor cells in severe congenital form of DM1, and his experimental results indicate that defects in the behaviour of satellite cells could be involved in the progressive distal muscle atrophy present in the adult form of the DM1 disease. 
Manuela Malatesta is a researcher at the University of Verona. She has been assistant at the Centre de Microscopie Electronique of the University of Lausanne (Switzerland) where she specialized in electron microscopy and ultrastructural cytochemistry. By combining morphological, histochemical and immunohistochemical analyses at light and electron microscopy she focussed her studies on the structural and functional alterations of RNA transcription and processing in different tissues of aged rodents, including skeletal muscle. She is also involved in a concerted research on the cellular basis of DMs: using microscopical, histochemical and molecular approaches ex vivo and in vitro she demonstrated that both mutations lead to the ectopic nuclear sequestration of several splicing factors causing alteration of messenger RNA processing which is in turn responsible for the multisystemic clinical features typical of these pathologies. Moreover, she found that myotonic dystrophy and sarcopenia share several cell nuclear mechanisms responsible for nuclear dysfunction, opening interesting perspectives for the research of the common bases of skeletal muscle wasting. Marzia Giagnacovo is a PhD student at the Department of Biology and Biotechnology of the University of Pavia, where she is working on the histological, histochemical and molecular features of skeletal muscle cells in aging mice and in human subjects affected by myotonic dystrophy.

Giovanni Meola is full professor of Neurology at the University of Milan, and Director of the Department and U.O.C. of Neurology/Stroke Unit at the IRCCS Policlinico San Donato. Pupil of the late lamented Professor Guglielmo Scarlato, he specialized in Neurology at the University of Newcastle Upon Tyne (UK), the Columbia University in New York (USA), and the Universities of Montreal and Quebec (Canada). Since 1995, Giovanni Meola is visiting Professor at the Department of Neurology, University of Rochester, N.Y. (USA) and since 2009 at the Department of Neurology, University of Beograd (Serbia).Over the last thirty years, he performed basic and clinical studies on neuromuscular diseases, with special attention to DMs. With the aim to promote researches on these pathologies and provide support to young researchers in this field, he founded in 2004 the Centre for the Study of Neuromuscular Diseases (CMN; http://www.associazionecmn.com/) and very recently, in December 2011, the Foundation for Myotonic Diseases (FMM; http://www.fondazionemalattiemiotoniche.org/). The FMM, recog- 
nized by the Regione Lombardia, strongly supports basic and clinical researches in the field of myotonic dystrophies. In addition, the Foundation also supports meeting, like the present one organized by Istituto Lombardo Accademia di Scienze e Lettere, to improve knowledge in the field of myotonic disorders, particularly DMs. 